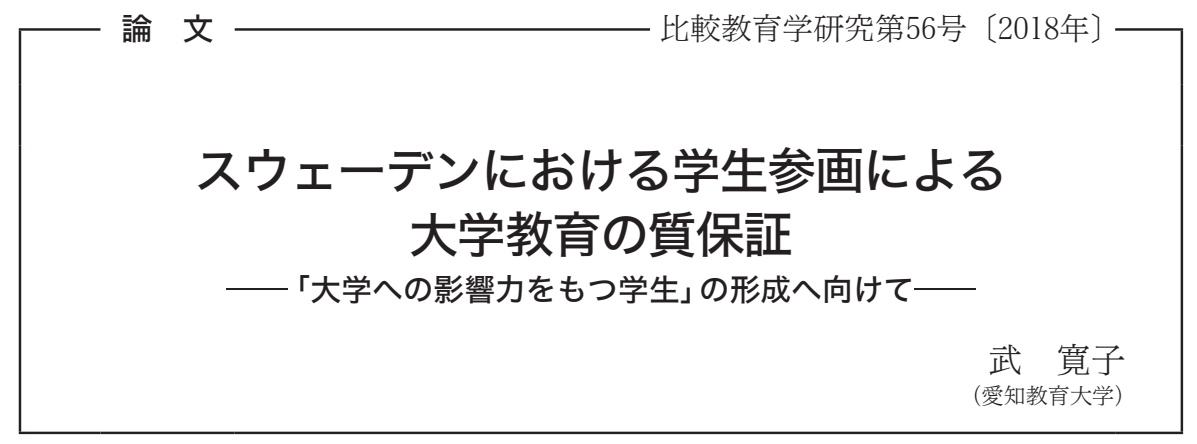

\title{
はじめに
}

本稿の目的は、スウェーデンの大学教育の質保証における学生参画について、 学生参画の制度的基盤を分析し、日本に抢ける学生参画による大学教育の質保 証への示唆を導き出すことである。

大学教育を受ける機会や場所が多様化している近年において、より多くの学 生を呼び込むために大学は自身の教育の質を高め、その教育内容を保証するこ とが、加速する高等教育市場で生き残るための重要課題の一つとなっている。 大学教育の制度、内容、枠組など大学教育に求められる様々な変化に対応する ためにも、学生の視点は欠かせないものと捉えられている。たとえば、ヨー ロッパの共通的な質保証枠組を提案する ENQA（European Association for Quality Assurance in Higher Education：ヨーロッパ高等教育質保証協会）は、学 生中心の学修スタイルを実現するために、大学の教育プロセス、成績評価、質 保証の場に打いて学生を参画させることを提案している。イギリスやオースト ラリアでも学生の学修を高めるために大学教育の質保証に学生を参画させる取 り組みが進められている（Coates 2005）。日本でも一部の大学に招いて、学生 がFD（Faculty Development）活動を通じて教学改善に取り組んだりして、学生 参画による教育の質保証が進められている（沖 2016）。日本の大学で今後さら に学生参画を展開するためには、学生が大学運営や教育の意思決定に参画する 制度や仕組みを構築することの必要性が指摘されている（沖 2016）。

スウェーデンでは、1977年の高等教育改革より学生は大学の政策運営に抒 
けるパートナーとみなされ、議決権をもつ重要なアクターとして、国レベル、 組織レベルで高等教育政策に関与してきた。スウェーデンでは大学教育の質保 証への学生参画は法律で定められており、学生 ${ }^{(1)} に は$ 意思決定プロセスに関与 するための権利が与えられていることから、同国における学生参画による大学 教育の質保証は理想的で先進的な状況だといえょう。しかし、2010年に学生 の代表者として機能していた学生組合への加盟が強制から任意制になったこと で、2017年には組合に加盟している学生の割合が $42 \%$ にな、学生の大学へ の影響力の低下が懸念されている（UKÄ 2017a）。

スウェーデンの高等教育や質保証制度に関する先行研究については、アメリ カやオランダの事例と比較したもの (Culver and Warfvinge 2013; Teelken and Wihlborg 2010）や学修成果の評価に関するもの（Take 2013）がある。新しい 質保証枠組みについては、国際的な視点と内部質保証を重視したものであるこ とが指摘されている（武 2016; Adomson and Gougoulakis 2017）。内部質保証は 学生の視点が重視されていることが明らかにされている（武 2017）にもかか わらず、質保証における学生参画の制度的検討はなされていない。そこで本稿 では、スウェーデンにおける大学が質保証への学生参画をいかに確保し、大学 への影響力をもつ学生、つまり大学教育の質保証に関与する学生を形成しょう としているのかを制度的側面から考察する。同国の学生参画が、Kafu（2013） のいうところによる、学生、教員、大学、政府による㗢きかけでいかに成立し ているのかを考察するためには、そもそも学生参画についてどのような制度が 構築されているのかを考察することが重要だと考えるからである。

本稿では、スウェーデンにおける大学教育の質保証への学生参画について、 まずは高等教育法においていかに学生参画を権利として保証しているのかを確 認する。学生参画に関する制度的基盤をふまえた上で、学生の代表者として機 能する学生組合と大学教育の質保証との関連、大学の運営、教育への直接的・ 間接的な学生参画について考察する。それにより、学生組合への加盟が低下す る同国において、いかに大学教育の質保証への学生参画を高め、学生の大学へ の影響力を形成しょうとしているのかを分析することが可能だと考える。最後 に、日本の大学教育の質保証への学生参画について、質保証への学生の関与を 高めるための示唆を導き出す。 


\section{1. 学生参画の定義}

学生参画による大学教育の質保証が重視されているのは、大学が教育改善を 進めるうえで学生の状況を把握し、学生の学修成果を高める必要があると考え られているからである。Coates（2005）によると、大学が学生の状況を把握し、 教育を改善することで生産的な学修を実現することができるという。また、質 保証に学生を参画させることで、学修成果が高まるなどの効果的な影響が指摘 されている (Coates 2005; Carey 2013; Millard, Bartholomew, Brand and Nygaard 2013)。学生参画による大学教育の質保証は、学生の意見を取り入れて教育を 改善することになり、こうしたプロセスによる教育改善は学生を中心にした指 導にも関連すると考えられている。

しかし、大学教育の質保証への学生参画については、イギリス、アメリカ合 衆国、オーストラリアなどの国々において進められているが、統一された明確 な定義はなく（Coates 2005）、国や組織によってその定義、範囲、実態は多様 である。Kafu（2013）は、学生参画に統一された定義がないことをふまえた上 で、4つの側面で学生参画を分析している。すなわち、行動的側面、心理的側 面、社会文化的側面、総合的側面である。Kafuによると、学生参画には、(1) 学生の実際の行動（行動的側面）、(2)大学への所属意識 (心理的側面)、(3)学生 参画に影響を及ぼす大学のもつ文化や政治的側面（社会文化的側面）、(4)学生 のモチベーションや期待感なども含めた広範囲な量的調査によって学生の学修 環境や状況を把握する（総合的側面）、に分類される。また、Healeyら（2010） は、学生参画をマクロ、メゾ、ミクロのレベルに分けたものを提案している。 大学の政策運営への参画（マクロ）、大学における内部質保証への参画（メゾ）、 学生個人の学修活動への参画（ミクロ）に分類される。学生参画の内容は、組 織レベルの会議への実際の参加や学生調査や授業評価などによる調査への参加 も指すという。学生参画には学生が実際に大学の教育プロセスや評価に関与す るという直接的な面と、学生の知識、経験などを踏まえて大学教育の政策に影 響を与えるという間接的な面の両方があるということである。さらに Kafuの 主張するところによると、学生参画を分析するには、大学が学生の要求に応じ 
ることで、学生の教育的成果も高まったのか、それぞれの関連性を調査するこ とが必要だという。そして、学生参画を高めるためには、学生、教員、大学、 政府のそれぞれの㗢きがけがより重要であると言及する。つまり、学生を、大 学教育を改善するためのパートナーとみなして、教育プロセスに参画させる制 度を構築することで、学生参画による大学教育の質保証が実現されるのである (Carey 2013)。

学生参画による大学教育の質保証とは、学生の意見を把握するための調査を する「だけ」ではなく、学生に教育に関する委員会や組織に出席させる「だ け」でもなく、実際の関与のことを指している。そこで、スウェーデンにおけ る学生参画を論じるうえで、本稿における学生参画を明確にしておきたい。す なわち本稿における学生参画とは、大学が学生の立場を対等にとらえ、学生の 意見を汲み取って、教育・運営に反映させるプロセスまたは方法のことを指す。

スウェーデンでは、学生を大学の教育評価などに参画させる権利を保証して おり、この制度的基盤が学生参画を実現させている。次節では、高等教育法、 学生組合規則を中心に取り上げ、これらの法規において学生参画がいかに構築 されているのかを考察する。

\section{2. 高等教育法などにみる学生参画}

スウェーデンは1977年の高等教育改革以降、大学の政策運営における学生 の参画が保証されており、高等教育法においてもそのことが明記されている (Högskolelag 1992: 1434)。歴史的にみても、学生が大学教育の政策、評価に参 画することの基盤が構築されている。

ではまず、高等教育法、学生組合規則（Studentkårsförordning）において、大 学教育への学生参画がどのように定められているのかを確認する。

高等教育法 第 1 条 4 節

「学生は、高等教育機関の提供するコースやプログラムに影響をおよぼす 権利が与えられている。高等教育機関はコースやプログラムの継続的な向 上のために学生が積極的に活動できるように努めなければならない。」 
高等教育法 第 2 条7節

「学生はコースやプログラム、学生に関する決定や制度が整えられる際、 自身の意見を発言する権利が与えられる」

高等教育法では、学生が大学教育に関する意見を発信し、大学教育の質向上、 改善のための影響力をもっていることを明記している。大学は、学生が教育に 関する意見を表明し、大学の教育改善に関与することが可能な環境を整備しな ければならない。

次に、学生組合規則がどのような機能を有しているのかを確認する。ス ウェーデンの大学における学生組合は、学生を代表する組織として機能してお り、高等教育に関連する国レベルの委員会、大学レベルの組織、委員会に参画 する権利を有している。学生組合規則によると、学生組合には以下のような機 能がある。

学生組合規則 第 7 節

「高等教育機関における学生組合は、学生の代表者を任命、もしくは解任 することができる。

複数の学生組合が活動する高等教育機関における代表をする際、または学 生組合に関する決定や制度が整えられる際、上記の規則は、学生組合によ る合意の上、満たされなければならない。

学生組合の合意に至らなかった場合、学生組合との協議を通じて、高等教 育機関が学生の代表者の任命を決定することができる。」

学生組合規則 第 8 節

「学生の代表者は、学生組合員ではない学生の代表も務める。」

学生組合規則 第 9 節

「高等教育機関に学生組合が存在しない場合、高等教育機関が直接的もし くは間接的に学生を選出するための手配をしなければならない。」 
学生組合は、学生の代表者として任命され結成された組織である。学生組合 が存在しない場合、大学側が学生の代表者を選出しなければならない。また、 学生組合は、組合に加入していない学生の代表者でなければならない。大学教 育や学生自身の状況を改善するために、学生は自らの意見を大学に伝えること が可能な環境が整えられ、大学教育の政策運営に関与することが求められてい る。スウェーデンの大学にとって、学生は大学の質保証や教育改善にとって欠 かせない存在なのである。

\section{3. 大学教育の質保証と学生組合 : 学生の大学への影響力}

\section{（1）学生組合の主な業務}

スウェーデン国内には、28の大学が存在する ${ }^{(2)}$ 。各大学には複数の学生組合 ${ }^{(3)}$ が存在し、大学教育の質保証に関与する学生組織として活動している。国レべ ルの質保証枠組の策定に関しては、全国学生組合（SFS：Sveriges förenade studentkårer, The Swedish National Union of Students）が学生の代表として決定過 程に関与している。

SFS は、1921 年に設立された。現在は 47 の組合が加盟しており、約 27 万人 の学部生、院生が所属している。また、SFS は国際的な活動も展開しており、 ヨーロッパの学生組織である、ヨーロッパ学生組合（the European Students' Union）にも加盟している。SFS は、各地の大学における学生組合を取りまと める組織として、国家質保証枠組の構築段階から参画しており、ボローニャ・ プロセスにおいて注目されている質保証への学生参画のための活動にとって重 要な役割を担っている。

SFS の目的は、学生の教育研究と福利厚生の充実である。これらの 2 点は、 学生の権利と義務として重視されている。たとえば、学生の健康・福利厚生へ の対応、住居の整備、あらゆる差別の是正、成績や試験に関する提議、授業内 容や方法の改善要求、大学の年次報告書の作成への参加、子ぞもをもつ学生に 対する配慮などと多岐にわたり、学生サービスの一端を担っている。さらに 2010 年以降、新たに重視されている点は、「学生の大学への影響力」である。 
この背景には、2010年に学生の学生組合への加盟が強制から任意になったこ とが挙げられる ${ }^{(4)}$ 。SFSらは、学生組合への加盟が任意になったことは、短期 的にみれば「学生の大学への影響力」の低下に影響しないが、長期的にみると 学生参画による教育の質保証に差し響くと懸念を示している (Andersson 2012)。実際に組合に加盟している学生は、全学生のうち 42\%であ り、半数にも満たない (UKÄ 2017a)。特に規模の小さい組合の場合、新しい メンバーの加入者数が減少しており、そのことによって組合費 ${ }^{(5)}$ の収入が減少 し、経済的な打撃を受けているという。一方で、薬学、工学、経済学などの比 較的学生数の多いプログラムの組合は、任意制による打撃を受けてはいないと いう。こうしたことから、長期的にみれば組合間やプログラム間における組合 活動の差異が大きくなり、学生の影響力に差異が生じ、大学教育の質の低下に つながることが不安視されている。

SFS は、これまでにも学生の学修や生活環境を向上させるために様々な調査 報告を社会や政府に対して行ってきた。たとえば、学生がいかに奨学金ローン の返済にあたっているのか、住居にどれくらいの金額を費やしているのか、大 学近辺で賃貸可能な住居が不足していて学生の住環境が良くないこと ${ }^{(6)}$ などに ついてである。学生の状況を社会に向けて発信することも、SFS の重要な役割 となっている。

\section{（2）大学教育の質保証と学生組合}

学生組合による働きかけが大学教育の質に影響を与えた出来事として、たと えば、大学の学修支援の取り組みに影響を与えた事例がある。スウェーデンの 高等教育法には、学生が卒業時に修得するべき学修成果が定められている。学 修成果について、SFS は、大学は学生が高等教育法に記載されている通りの知 識、スキル、態度を修得するための教育を行っていない、と批判した（The Swedish National Union of Students 2014)。大学での講義は、教員の研究テーマ に沿った内容が伝えられ、教員は大学で教育するための教育を受けていないこ とを提議した。この文書では、大学教育の質を高めるために、研究者および教 育者としての大学教員を育成することを目的とした博士課程教育の重要性を主 張している。SFS は大学総長らと会談を行ったり、スウェーデン高等教育協会 
( SUHF : Sveriges universitets- och högskoleförbund, The Association of Swedish Higher Education）らとともにキャンペーンを行ったりして、大学教育の改善 を訴えた (SFS 2015) ${ }^{(7)}$ 。複数の大学の学生組合がこのキャンペーンに賛同し、 大学における学生中心の学修について訴えた ${ }^{(8)}$ 。そしてこの流れは、政府が博 士課程教育に拈けるキャリア支援や学修支援の重要性をみとめることにつな がったのである (SOU 2016) ${ }^{(9)}$ 。さらに、大学にとっても自身の教育を改善さ せる契機となった。例えば、オレブロ大学では大学教授法の授業を博士課程の 学生を対象に開講し、その中でティーチング・ポートフォリオ作成など学修支 援のスキルを高める内容を定めている。SFSが学生中心の教育の必要性を訴え て、大学教育の改善につながった事例である。

スウェーデンにおける大学教育の質向上とは、カリキュラムや学修成果の改 善といった教育研究面だけを指しているのではなく、大学という組織に身を置 く「社会人」として生活するにあたって保証されるべき環境の整備も指してい る。たとえば、高等教育法には、学生が身に付けるべき専門分野の知識や理解 だけでなく、倫理的な道徳観についても言及されている。ここでいう倫理的な 道徳観とは、男女差別、経済的・民族的差別への配慮、民主的な考えをもつこ とを指しており、これらの倫理的視点は、大学教育の質保証としても重要な項 目となっている。仮に学生が大学でこれらの価值観を軽視した教育や行為に遭 遇した場合、学生は学生組合を通じて異議申し立てを行う権利が認められてい るのである。

以上のことから、スウェーデンにおける学生組合の活動は、単なる社会参加 や体験学習の経験を積むためのものではなく、大学教育の質向上のために必要 な教育内容や教育機会を発信する、大学教育政策をすすめる上での連携者とし て機能している。

次節では、大学教育の質保証における学生参画について、まずは国家質保証 枠組の全体像について述べた上で、大学レベル、個人レベルでの学生参画につ いても考察する。 


\section{4. 大学教育の質保証における学生参画}

スウェーデンは、これまでに3度の国家的な質保証枠組を実施してきた。第 一次質保証枠組（2009 2010年）は、（1）学士課程の基準認定（accreditation）、 （2）テーマ別評価、（3）教育に関する評価、（4）研究の質に関する評価、（5） 卓越した教育業績の評価、で構成されていた。

第二次質保証枠組（2011～2014年）は、アクレディテーションとプログラ ム評価の二つで構成され、プログラム評価において学生の学修成果を評価の対 象とした。学修成果に焦点をあてた第二次質保証枠組は、その結果が追加的資 金に影響するため、長期的にみると教育の平等に影響を与えかねないとして、 小規模の大学や学生組合から批判がなされた（Regeringens proposition 2010）。

また、この第二次質保証枠組は、ヨーロッパ域内においても否定的な評価が なされた。ENQA は、スウェーデンの第二次質保証枠組がヨーロッパ共通の質 保証枠組であるヨーロッパ・スタンダート・ガイドライン (ESG : Europe Standard Guideline）に沿っていないことを非難したのである（ENQA 2012）。 ENQA は、内部質保証が効果的に活用されていないこと、過度に学生の学修成 果に焦点をあてた評価がされていること、大学の自己評価に明確な指針がない ことから、スウェーデンをENQAの評価委員会メンバーから除外するに至った (Culver and Warfvinge 2013)。

こうした第二次質保証枠組への国内外からの批判を受けて、2017年から運 用されている第三次質保証枠組は、次の点を重視している。（1）内部質保証の 関連を強化すること、（2）国際的な枠組を導入すること、（3）質保証における 学生の役割を強化すること、（4）大学教育の労働社会へのインパクトを明確に

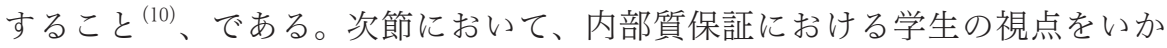
に強化しようとしているのかを考察する。

\section{（1） 内部質保証における学生参画}

第三次質保証枠組では、学生の役割を強化することを目指している。第三次 質保証枠組構築のための検討会では、大学は評価の過程でいかに学生の視点を 
取り入れるか、評価者としての学生を確保するか、学生へのインタビュー調査 を行い、大学が自身の教育改善のために学生の意見をいかに汲み取っているの かを調査することが提案されている（UKÄ 2016）。高等教育局（UKÄ： Universitetskanslersämbetet）の懸念は、学生組合への加盟が任意になったこと で、評価に参画している学生の意見が全学生の代表として機能するのか、学生 組合ではない学生の意見も代表するのかということである。そこで評価者とし ての学生を選出する際、UKÄはSFS と協力して各大学の学生組合から学生の 代表者を集めた「学生プール」を創設し、評価者としての学生を確保すること が議論された（UKÄ 2016）。また、学生の評価者としての質を高めるために、 ESG や評価の視点に関する研修期間を設けることも計画されている（UKÄ 2016)。

第三次質保証枠組の学生の視点において重視されているのは、学生への フィードバックである。教育の改善と質保証のために、評価結果を学生に報告 し、学生と教員が協㗢で学生の学修について分析を行い、いかに学生の教育の 質を高めることができるのかについて議論することを目指している。評価への 学生の参画を高めるために、単に教育評価の結果を学生に返すだけでなく分析 の過程においても学生参画を促し、参画の意義を高めょうとしている。

それでは、大学の内部質保証レベルでの学生参画に関する制度についてみて みよう。本節では、ルンド大学の取り組みを挙げる。ルンド大学は国内で 2 番 目に設立された総合大学であり、歴史的にも同国の高等教育の発展に大きく寄 与してきた。1980年代以降、内部質保証の評価手法を独自に開発しており、 他大学が内部質保証制度を構築する際のモデルとされていることから、学生参 画による質保証制度を考察するのに適していると考えられる。ルンド大学では、 学生とのパートナーシップ・モデルを構築しており、学生の意見を質保証に取 り入れるための整備が存在している。同大学の戦略計画には、学部単位で複数 の学生から教育プログラムに関する意見を聞き取り、学生の大学への影響力を 高めることが大学の質保証であると明確に示している（Lund Universitet 2012）。

同大学は、すべてのプログラム、学部に所属する学部生、院生の学修の質向 上を目指して、外部評価、内部質保証に関する資料へのアクセスを許可し、学 生がこれらの取り組みに参画できるようにしている。実際の議論への参画は、 
学生組合が選出した学生の代表者が担うことになる。しかし、代表者ではない それ以外の学生も、これらの資料を入手することが認められている。学生はプ ログラム、学部、大学のすべてのレベルにおける内部質保証への参画が認めら れているため、質評価オフィスが、教育の質保証に関する助言やサポートを実 施している。外部評価や内部質保証への対応が理由で学生が授業に出席できな い場合は、学部やプログラムの教職員が授業の出席に相当する代替の課題等を 学生に提案しなければならない。

その他にも、内部質保証への学生参画として、新入生調査と授業評価がある。 新入生調査は、学生の大学入学時までの経験を把握するために実施されている。 新入生調査はオンラインで実施され、すべての学生に対して送付される。全学 部共通の項目と学部ごとで設置された項目があり、結果は全学および学部ごと に報告される。

授業評価もまた、内部質保証に学生が参画するための重要な手段だと考えら れている（Healey et al. 2010）。学生は授業評価を通じて、自身が受けてきた 教育に関する意見を表す権利が認められており、大学側は授業評価を実施する ことが義務になっている。授業評価の調査項目は、学生自身について（授業へ の準備時間など）、教員（教員は適切な指導をしていたか、学生の自律的な学 修を促す指導をしていたか、など）、試験（試験内容が適切であったかなど） などである。授業評価の分析に関する報告書は、全学で共有するだけでなく、 学生にもフィードバックしている。各学部は、この報告書をもとにどのように 教育を改善するのかを議論しなければならない。

ルンド大学の事例から、内部質保証への学生の参画は、大学教育の質保証に とって至極当然のこととして認められていることがわかる。学生組合を通じて 学生の代表として選出されていない他の学生に対しても、授業評価や新入生調 査といった調査を通じて学生の意見を聞き取れるように制度が構築されており、 直接的、間接的な内部質保証への学生参画が認められている。

\section{（2）学生個人の学修活動への参画}

学生個人や他の学生の学修活動への参画もまた、学生参画による教育の質保 証に関連する (Healey et al. 2010)。本節では、学生個人や他の学生の学修活 
動への参画について、全国学生調査の結果からその状況を把握する。この学生 調査は、学生の学修状況や学修プロセスを把握し、学生の視点を大学教育の改 善に役立てることを目的としている。スウェーデンでは、2002年に初めて国 内の学部生を対象にした大学教育に関するアンケート調査「学生の鏡像 (Studentspegeln: Students ' Mirror)」を実施した ${ }^{(11)}$ 。その後、学部生対象の調査 は2007年と2016年に行われた。本節では、スウェーデンの学生の学修状況に

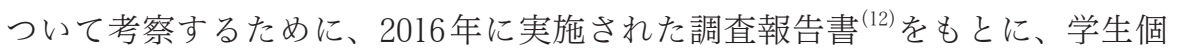
人の学修活動への参画に関連する項目として「学生間の協働」の結果を取り上 げる(13)。

この項目では、学生が他の学生と協働して課題に取り組んだか、協調性やコ ミュニケーションを身に付けることができたのかを尋ねている。質問内容は、 「授業中、クラスメイトと協働で課題に取り組んだ」、授業以外でクラスメイ トと協働で課題に取り組んだ」「他者と協力することができた」で構成される。

「他者と協力することができた」について、学生の $77 \%$ 「てときどきしてい た」よくしていた」と回答しており、授業内外で他の学生とともにレポートや

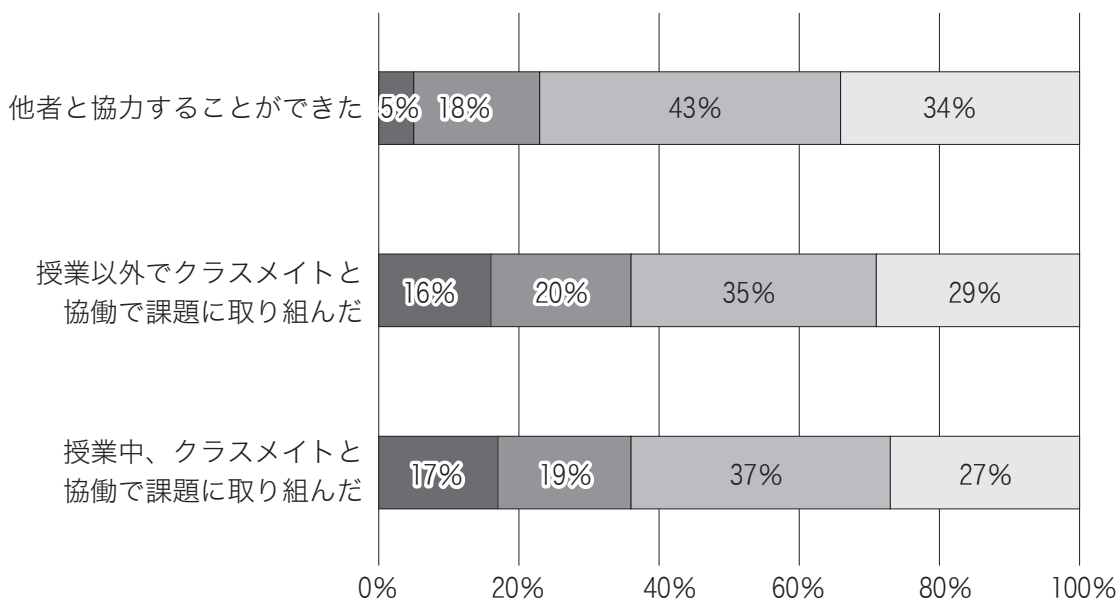

$\square$ まったくしていない $\square$ ほとんどしていない $\square$ 時々していた $\square$ よくしていた

図 1 他の学生との協働に関する学生の自己評価

出所) Universitetskanslersämbetet (2017b) Rapport 2017:3Studentspegeln 2016.より筆者作成。 
発表などの課題に取り組み、他の学生の学修活動に参画する環境にいることが 推察できる。2007年の調査では、多くの課程において、他者と協働して発表 や課題に取り組む教育内容が削減されたことが問題視された（Högskoleverket 2007）けれども、他者と協働して課題に取り組むことを手法とする学生参加型 の授業実践について、その指導方法、評価方法などのティップスが一部の大学 において作成されるといった学生中心の学修が環境として整えられていること が窥える。2016年度の調査による新たな課題は、専門分野間での違いである。 他者と協働しながら学修する授業スタイルは、工学などの理系分野で「よくし

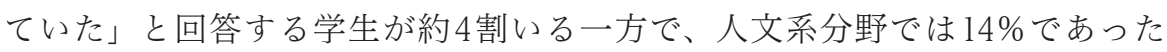
(UKÄ 2017b)。工学や理系分野では、チームで研究を行うことがあるため、 専門分野による教育方法の違いが当該項目における回答の差異につながったと 考えられる。

学生間の学修活動については専攻分野間での結果の差異に問題が残されてい るけれども、全体的にみて、学生同士が学び合う環境が整備されているといえ るだろう。「他の学生の学修活動への参画」は、日々の講義の中で意識されて いることでもある。例えば、グループ・ディスカッションをしたり、他の学生 と協働でレポートや口頭発表の準備をしたりして、相互に学修活動を高める教 育が重視されている。他の学生と協㗢で課題に取り組むことによって、自分の 意見を伝えたり、まとめたりすることで、一人で課題に取り組むよりも多くの 教育効果が期待でき、また、こうした経験が将来の社会人生活においても活か せると考えられていることが背景にある (Högskoleverket 2007)。日々の学修活 動において、学生は他者と協働しながら学ぶことができる環境にいるといえる。

\section{（3）大学理事会への学生参画}

本節では、各大学でどのように学生が大学の政策運営に関わっているのか、 大学が発行する学生ガイドラインや教授会、理事会などの内部資料をもとに取 り上げる。

高等教育法では、学生の大学理事会への参画を認め、高等教育の改善、発展 に関与する権利が認められている。15名で構成される大学理事会のうち、3名 の学生を選出しなければならない( ${ }^{(14)}$ 。また、学生組合規則においても、学生 
は大学の意思・政策の決定プロセスに関与できることが明記されている。大学 の意思・政策の決定プロセスに関与するために学生側に求められているのは、 大学に関する知識をもっていることである。学生代表の 3 名は、学生組合から 選出されることから、学生は組合を通じて大学教育の質保証に関与する権利を 有している。その権利とは、（1）大学のあらゆる意思決定プロセスに関与する ことができる、（2）自己評価、外部評価の際、評価側のメンバーとして加入で きる、（3）大学の会計年次報告に関与することができる、（4）学生が在籍する コースの教育内容に関する評価を行うことができる、である。一方で、教員人 事に関する審議の際は退席しなければならないといった一部制限もある。

では、大学におけるどのような議論に学生は参画しているのだろうか。ルン ド大学の大学戦略計画書をみると、「質を保証するために、学生の影響力を高 めること」を揭げている。また、学生を大学のパートナーとして認め、対話関 係にあることを示している（Lund Universitet 2012）。このことは、教員、学生、 職員は対等な関係にあることを指している。三者の対等な関係のうえで、学生 は大学、学部、学科レベルでの意思決定プロセスに参画している。たとえば、 理事会では次のような審議がされ、その場に学生は参画し議決権を有してい る；（1）入学者数の近年の動向について、（2）教員人事（新規採用、昇進）に ついて、（3）新たに建設するキャンパスのコンセプトについて、（4）2014年 度の大学全体の収支バランス。

ウプサラ大学では、学生を「大学運営における協働者」として明示している (Uppsala University 2014)。プログラム評価に学生が参画することで、プログ ラムやコースの教育内容を開発し、改善するために重要な役割を担っている存 在だと認めている。実際に理事会では次のような審議が行われており、学生も 参画している；（1）新たな研究費の獲得について、（2）今年度の研究費の獲得 と受賞について、（3）留学生の受け入れ、（4）新たな保育プログラムの設置に ついて、（5）教員の採用について。

ストックホルム大学では、教育に関するあらゆる規則、文書を学生が入手で きることを政策文書の中で明記している（Stockholm Universitet 2012）。実際の 理事会の内容をみてみると、（1）2015年度の自己評価（Audit）の計画につい て、（2）2015年度ストックホルム大学のリスク分析について、（3）ストック 
ホルム大学政策の決議について、（3）学部の統合について、（4）合否基準の改 定に関する決議。

以上のように、各大学ともに政策文書内に学生との関係を明記し、組織レべ ルの会議への学生の出席を認め、会議資料の情報を開示するなどして学生参画 の機会を設けている。

\section{おわりに}

スウェーデンでは、高等教育法や学生組合規則において、学生の内部質保証 への参画が権利として確保されている。各大学は、高等教育法に則り、質保証 における学生の役割や立場を明示している。学生は、大学教育の質保証、改善 にとって重要なパートナーと認められ、大学の運営、経営、財政、教育などあ らゆる事項に関する決定プロセスに参画する権利を有する。さらに、学生は教 育の評価、成績や試験に関する疑義を発する権利を有しており、大学の経営、 運営方針、財政に関する文書へのアクセスも可能である。各大学は、各プログ ラムにおける教育環境の整備から大学の運営方針に至るまで、学生が参画する 機会を設けなければならない。

学生組合は2010年より学生の加盟が任意制になったものの、大学生活を送 るにあたって重要な組織であることに変わりはない。しかし学生組合への強制 加入が廃止されたことで、学生組合に加入する学生数が減少すること、学生に よる質保証参画への意識が低下することが、SFSだけでなく政府やUKÄによっ ても懸念されている。この点について、実際に加入者数の減少による経済的な 問題が起きている組合もあり、プログラムや大学間における差異もみられつつ ある。このまま加入者が減ると、学生組合が学生の代表として機能していると はいい難くなるだろう。組合への加盟が任意制になっても学生参画による質保 証を維持するには、新しい質保証枠組において学生の視点を重視することで、 低下しつつある学生の質保証への参画の意識を大学、政府、国からの㗢きかけ を得て高めることが重要な施策となる。つまり現状の学生参画は、UKÄや大 学に主導されて機能しうる。しかしこれは、学生参画の政治的な強要を意味す るのではなく、学生参画という共通のテーマについてUKÄや大学が学生の意 
見をいかに拾い上げていくのかを制度的に下支えするものである。

スウェーデンでは、学生は大学の政策運営上のパートナーであることが法律 上定められており、教員と学生の対等な関係が意識されてきた。スウェーデン の学生参画は、高等教育法において保証されているということ、国、政府、大 学、学生からの働きがけで質保証への学生参画が制度的に構築されていること から、学生参画に関する歴史的経緯が日本の状況とは大きく異なる。こうした 特徵をふまえた上で、日本の大学の質保証において学生参画を進めるために、 スウェーデンから学べることについて考察したい。スウェーデンにおける新し い質保証枠組では学生の内部質保証への参画の強化を揭げており、その新たな 視点として学生へのフィードバックを挙げて、単に結果を報告するだけではな く分析の過程においても学生の視点を取り入れることを重視している。たとえ ば、内部質保証の手段の一つとして実施される授業評価は、その結果が教育改 善につながるように可視化され、ファカルディー・デベロップメントのために 活用される。学生から集めた「声」をデータとして有効活用し、学内の教育改 善へとつなげるための仕組みを構築している。このことは、学生に無駄な参加 はさせない、そして、参加させた意味を明示することを大学が意識しているこ との表れだといえる。大学の内部質保証に学生を形式的に参画させるのではな く、参画させたことで「何が」どのように」変わったのかを学生にフィード バックし、明らかにすることが、大学の質保証に学生を参画させるうえで必要 になると考えられる。日本においても学生参画による教学改善が展開されてい るが、学生には意思決定権は付与されておらず、また、大学運営に関与する制 度も構築されていない。日本の大学の質保証において、学生自治会や学生 FD 活動に参加していない学生以外の参画を促すためには、単に調査や評価に参加 させる「だけ」ではなく、これらに参加した意義が見いだせるような結果（具 体的な教育改善や、どのような議論が学内で行われたのか、など）を学生に提 示することが求められるであろう。

本稿は、学生参画による大学教育の質保証に関する制度的検討を射程とした。 本研究を踏まえて、実際に大学の学生参画がいかに実現され、大学への影響力 をもつ学生が形成されているのか、学生組合や学生へのインタビュー調査を実 施して考察することを今後の課題としたい。 


\section{【謝辞】}

本稿は、科学研究費基盤研究 (B)「学生参画による質保証の国際比較一学生との対話を反映 した大学教育の質の向上一」(代表者：田中正弘)による助成を受けて実施したものです。

\section{【注】}

(1) スウェーデンにおける学生の特徵として、大学に入学する年齢層が高いことが挙げられ る (入学時の平均年齢 24 歳 : OECD平均 22 歳) (OECD 2016)。高校卒業後すぐに大学へ進学 するのではなく、社会経験を積んでから大学へ進学する学生が多く存在し、日本における 学生とは属性が異なる状況にある。

(2) 学士、修士、博士課程の教育を提供する国立大学 25 校、および私立大学 3 校。

（3）たとえば、ルンド大学には9つの学生組合が活動を展開しており、学部によって所属す る組合が異なる。組合によっては政党政治による影響を受けて主義やポリシーを揭げてい る場合もある。

（4）学生組合に加盟することを選択する権利を学生に委ねるという観点から、学生組合への 加盟が任意制になった (UKÄ 2017a)。

（5）たとえば、ストックホルム大学では、学期ごとに120クローネを支払わなければならな い。

(6) SFS (2017a) Studentbudget 2017.; SFS (2017b) SFS Bostadsrapport 2017-Bostadssituationen för landets studenter.

(7) SFS (2015) Alla fattar utom jag-Hur skapar vi förutsättningar för god undervisning?

(8) たとえば、ウプサラ大学やカールスタッド大学。

(9) SOU (2016) 2016: 29, Trygghet och attraktivitet - en forskarkarriär för framtiden.

（10）「（1）内部質保証の関連を強化すること」では、大学の内部質保証との一貫性を重視し ている。「(2) 国際的な枠組を導入すること」では、ESGの指標を取り入れた枠組を構築す る計画である。「(4) 大学教育の労働社会へのインパクトを明確にすること」では、労働組 合からの代表者の教育への評価を重視することで、教育内容の実用性を確保することを目 指している。(武 2016)

（11）これまでに、2003年に博士課程を対象に、2006年に修士課程の留学生を対象に、2007 年に学部生を対象に、2015年に学部生および博士課程の学生を対象に実施した。

（12）この調査票は、在籍する大学において少なくとも2セメスターの期間修学した学生で、 大学の在籍期間、取得単位数などに基づいた層別解析によって抽出された 11,031 人の学生

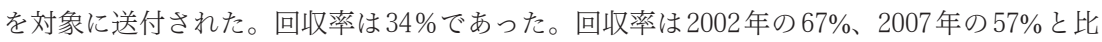
較して、最も低い数值である。低い回収率ではあるが、同国における学生の学修状況を把 握するための貴重な資料として本稿では分析の対象とした。

（13）調查項目は、（1）教養と価值観、（2）批判的考察、（3）学生間の協働、（4）コミュニケー ションの習得、（5）リーディング・ライティング・レポート作成に関するスキル、（6）教員 
によるサポート、によって構成されている。

（14）任期は 3 年である。

\section{【参考文献】}

沖裕貴 (2016)「日本の高等教育における『学生参画』の概念の再整理の試み一新たな『学生連

携』の概念をどう捉えるかー」『中部大学教育研究』No. 16、pp. 1-12。

武寛子 (2016)「スウェーデンにおける大学教育の新しい質保証枠組の構築に向けた動向」大学 教育研究』第24号、pp. 87-97.

(2017)「スウェーデンの大学における新しい内部質保証枠組に関する考察」『東海教 育社会学研究会』第8 8 回、於名古屋大学、発表レジュメ。

Andersson, F. (2012) Ökat beroende efter frihetsreformen? - Studentinflytandet två år efter kårobligatoriets avskaffande. Sveriges universitets- och högskoleförbund.

Adomson, L. and Gougoulakis, P. (2017) “Swedish Quality Assurance of Higher Education: From Enhancement to Results Control and Back to Enhancement?" . In Georgios K.M. Joshi and S. Paivandi (eds), Quality Assurance in Higher Education: A Global Perspective, Studera Press pp. $19-40$.

Carey,P. (2013) “Student Engagement: Stakeholder Perspectives on Course Representation in University Governance," Studies in Higher Education, Vol. 38, No. 9: pp. 1290-1304.

Coats, H. (2005) “The Value of Student Engagement for Higher Education Quality Assurance," Quality in Higher Education, Vol. 11, No. 11: pp. 25-36.

Culver, S.M. and Warfvinge, P. (2013) “Assessment, Accountability and Educational Quality in the

United States and Sweden," European Journal of Higher Education, Vol. 3, No. 1; pp. 10-23.

ENQA (2012) Swedish National Agency for Higher Education: Review of ENQA Membership.

Högskoleverket (2007) Rapport 2007:20 R, Studentspegeln 2007.

Högskolelag (1992:1434).

Healy, M. and Mason O ' conner, K. and Broadfoot, P. (2010) "Reflection on Engaging Students in the Process and Product of Strategy Development for Learning, Teaching and Assessment: an Institutional Case Study," International Journal of Academic Development, Vol. 15, No. 1: pp. 1932.

Kafu, E. R. (2013) “Framing Student Engagement in Higher Education," Studies in Higher Education, Vol. 28, No. 5: pp. 658-773.

Lunds universitet (2012) Strategisk plan för Lunds universitet 2012-2016.

Millard, L., Bartholomew, P., Brand, S. and Nygaard, C. (2013) “Why Student Engagement Matters” , In Nygaard, C. Brand, S., Bartholomew, P. and Millard, L. Student Engagement- Identity, Motivation and Community. UK, Libri Pubrishing.

$\operatorname{OECD}(2016)$ Education at a Glance.

Regerigens proposition (2010) 2009/10:139 Fokus på kunskap - kvalitet i den högre utbildningen.

Stockholms Universitiet(2012) Policy och riktlinjer för studentinflytande vid Stockholms universitet. 
Studentkårsförordning (SFS 2009:769)

Take,H. (2013) “Outcomes of Student Learning and the Learning Evaluation Approach in SwedenReconsideration of Evaluation Approach from the Perspective of a Student Survey” , Kobe Journal of Higher Education, No. 22: pp. 71-86.

Teelken,C. and Wihlborg, M. (2010) "Reflecting on the Bologna Outcome Space: Some Pitfalls to Avoid? Exploring Universities in Sweden and the Netherlands" , European Educational Research Journal, Vol. 9, No. 1, pp. 105-115.

The Swedish National Union of Students. (2014) Improving Teaching and Learning in Swedish Higher Education: A Student Centred Perspective. Stockholm, Globalt företagstryckeri.

Universitetskanslersämbetet (2016) Förslag till nytt nationellt kvalitetssystem för högre utbildning diskussionsunderlag inför dialogmöten i maj-juni 2016.

(2017a) Studentinflytandet - Kartlaggning och analys av studentinflytandets forutsattningar efter karobligatoriets avskaffande (dnr 111-99-16) .

- (2017b) Rapport 2017:3Studentspegeln 2016.

Uppsala University (2015) Guidelines for Uppsala University's Model for Educational Evaluations. 


\section{Student Engagement in Quality Assurance in University Education: The Formation of Students' Influence on Higher Education}

Hiroko TAKE

(Aichi University of Education)

In recent years, the diversification of opportunities and places to receive university education has accelerated the importance of quality improvement and quality assurance in university education. Student engagement has become an important perspective for understanding the various shifts required for institutions and the content and framework of university education.

In Sweden, students have been considered as a partner in the policy management of universities since the university education reforms of the 1970s. Students have been involved in higher education policy at a national and institutional level as key actors with the right of resolution. Students who are selected from the student union participate in committees and meetings as representatives. Student engagement at Swedish universities has been established based on efforts from the government, universities, faculty members and students. Student engagement in the quality assurance of university education is vital and already at an advanced stage, as student engagement has been ensured by law and students have the right to be involved in the decision-making processes of university management. However, students now have the right to choose if they will participate in the student union, something that was compulsory until 2010. This has led to a decline in student affiliation, with just $42 \%$ of students now participating in the student union. As a result, the decreased student influence on universities has become a concern (UKÄ 2017).

This article aims to analyse the system with respect to student engagement in quality assurance in university education in Sweden and suggest how to promote student engagement in Japan. First, the author examines how the higher education law ensures that student engagement is a right of students, including student engagement in university education quality assurance. Based on the legal infrastructure regarding student engagement, the author considers the relevance of the student union, which functions as the representative of students and is responsible for direct and indirect forms of student engagement in university administration and education, to quality assurance. It then analyses how Sweden, where the number of students affiliated to student unions is declining, is attempting to enhance student engagement and improve students' influence on universities. Finally, the study suggests 
approaches for student engagement in the quality assurance of university education in Japan.

In Sweden, student engagement in institutional quality assurance is ensured as a right by the higher education law and student union regulations. Each university clarifies students' role and position in quality assurance based on the law. Students are considered as an important partner in the improvement of university education and have the right to be involved in decision-making processes regarding university management, finance and education. Universities have to establish opportunities to engage students in issues ranging from the coordination of education programmes to management policy.

Student unions have a role in activities related to students' education and welfare. For example, they function as part of student services, supporting students' health and welfare, preventing any kind of discrimination, making proposals about grades and examinations and participating in producing annual reports. Students involved in student union activity are not only involved in social participation or work experience but also function as co-workers who disseminate student views about the education content that is required and opportunities for improvement in education.

The third national quality assurance framework was implemented in 2017. The new framework emphasises four points: (1) strengthening the connection with institutional quality assurance; (2) adopting the international framework; (3) strengthening the role of students in quality assurance; and (4) demonstrating university education's impact on economy and society. The framework clarifies the procedures for students as evaluators and students' role in institutional quality assurance and external evaluation based on the guidelines for student engagement proposed by the Bologna Process. The framework focuses on ensuring that institutional quality assurance has a student perspective. It ensures that universities learn from students' opinions regarding improvements and that there is discussion between faculty members and students about educational improvements. The new framework also proposes that universities implement interviews with students to take the student perspective into account in the process of evaluation.

Thus, in Sweden, students are recognised as a partner in university policy management and have an equal relationship with their teachers. The student union still remains an important organisation for students living on campus. However, if the number of students affiliating with the union continues to decrease, it might become difficult to claim that the union has the function of representing students. To maintain student engagement in quality assurance under optional affiliation, the new quality assurance framework adopts the significant strategy of focusing on the student perspective in order to respond to the decline in student consciousness regarding the importance of engaging in university 
quality assurance. Student engagement might now function not as the result of students' self-motivated involvement but as something that is led by the authorities and universities. This does not indicate political constraints but rather reveals that formative support from the authorities and universities is seen as the way to figure out students' voices.

The new quality assurance framework strengthens student engagement in quality assurance, and the new emphasis is on feedback from students. For example, the results of course evaluations, which have been implemented as one of the approaches towards institutional quality assurance, are used for faculty development. Universities use the "student voice" as data and connect it with educational improvement. This means that universities do not let students participate ineffectively; instead, they show the results or meaning of their participation. When it comes to encouraging student engagement in quality assurance, it is important that universities provide feedback to students on "what" has changed by their engagement and "how", rather than offering just a formal participation. To persuade students to engage in quality assurance in university education, universities are required not only to encourage students to participate in surveys and evaluation processes but also to show students the results of their engagement, such as clear educational improvements and the effects of student engagement on faculty debates. 